\section{OAK RIDGE Y-12 PLANT}

MARTIN MALIETTA

\section{ULTRASONIC CLEANING OF DEPLETED URANIUM MATERIAL AS AN ALTERNATIVE TO NITRIC ACID CLEANING}

\author{
L. E. Frye \\ Materials Engineering Department \\ Development Division \\ C. B. Senviel \\ Metal Preparation Division \\ Y-12 Plant
}

Date of Issue: May 28, 1991
MANAGED BY

MARTIN MARIETTA ENERGY SYSTEMS, INC.

FOR THE UNITED STATES

DEPARTMENT OF ENERGY
Prepared by the

Oak Ridge Y-12 Plant

P.O. Box 2009, Oak Ridge, Tennessee 37831 managed by

MARTIN MARIETTA ENERGY SYSTEMS, INC. for the

U.S. DEPARTMENT OF ENERGY under contract DE-AC05-840R21400 


\section{DISCLAIMER}

This report was prepared as an account of work sponsored by an agency of the United States Government. Neither the United States Government nor any agency Thereof, nor any of their employees, makes any warranty, express or implied, or assumes any legal liability or responsibility for the accuracy, completeness, or usefulness of any information, apparatus, product, or process disclosed, or represents that its use would not infringe privately owned rights. Reference herein to any specific commercial product, process, or service by trade name, trademark, manufacturer, or otherwise does not necessarily constitute or imply its endorsement, recommendation, or favoring by the United States Government or any agency thereof. The views and opinions of authors expressed herein do not necessarily state or reflect those of the United States Government or any agency thereof. 


\section{DISCLAIMER}

Portions of this document may be illegible in electronic image products. Images are produced from the best available original document. 


\title{
ULTRASONIC CLEANING OF DEPLETED URANIUM MATERIAL AS AN ALTERNATIVE TO NITRIC ACID CLEANING
}

\author{
L. E. Frye \\ Materials Engineering Department \\ Development Division \\ Oak Ridge Y-12 Plant* \\ Oak Ridge, Tennessee \\ C. B. Senviel \\ Metal Preparation Division \\ Y-12 Plant
}

\author{
$\mathrm{Y} / \mathrm{WP}--0002$ \\ DE91 014249
}

\section{SUMMARY}

Nitric acid is used to clean depleted uranium in the form of cast billets, and cast and wrought parts in the processing cycle and is the largest contributor of waste to the West End Treatment Facility (WETF). An estimated 27,000 gallons of liquid and 75 to $95 \%$ of all uranium received was sent to the WETF for processing from this facility in our baseline year. Because wrought parts account for the largest throughput at the nitric acid facility, an alternative cleaning method for these parts was examined first.

Test results on the first part type from the wrought family showed ultrasonic cleaning to be an effective cleaning method. Since the geometry for this part presented the most difficulty in terms of ultrasonic cleaning, the entire wrought family is expected to be moved from the nitric acid facility to the ultrasonic cleaning facility. As a result, there will be an $83 \%$ reduction in part throughput at the nitric acid facility which corresponds to a significant decrease in wastes sent to the WETF and a reduction in the generation and associated costs of wastes overall. This change also eliminated two building moves involving two RAD areas resulting in a part movement reduction of approximately $25 \%$ which is a significant cost savings.

*Managed for the U.S. Department of Energy by Martin Marietta Energy Systems, Inc., under contract DE-AC05-84OR21400. 


\section{BACKGROUND}

Currently, Nitric Acid is used to clean depleted uranium in the form of cast billets, cast parts, and wrought parts in the depleted uranium processing cycle. The purpose of the cleaning step is to comply with radiological guidelines on the movement of parts between operations areas with regard to removable contamination. These processes are under the responsibility of the Metal Preparation Division. Wastes from this facility contributed 27,000 gallons of liquid (nitric acid and water) and $75-95 \%$ of the total uranium received at the West End Treatment Facility (WETF) in the "baseline" year. The "baseline" year is defined in the Process Waste Assessment for depleted uranium. Records show the source of wastes to be the nitric acid tank (500 gal), rinse tank (500 gal), and mop water tank ( 400 gal) that are piped to an acid tanker for shipment to the WETF. Because wrought parts have the largest throughput at the nitric acid facility, an alternative cleaning method for these parts would greatly reduce the wastes going into the WETF by decreasing the volume of each of the listed waste sources. This report addresses the wrought parts only. A separate study is being undertaken on the cast parts and billets.

During the initial examination of possible alternative cleaning methods, it was discovered that the Metal Preparation Division was in the process of installing an Ultrasonic Rinse Tank for general purpose use. The Metal Preparation Division and the Waste Minimization Organization agreed to use this tank to determine the feasibility of using ultrasonic cleaning on wrought uranium parts and coordinated their efforts to expedite the installation process. Ultrasonic cleaning has been shown to be an effective means of cleaning in several areas in the Y-12 Plant.

In order to systematically examine the ultrasonic process in terms of health, safety, and environmental concerns, a Health Safety Readiness Review (HSRR) was conducted. Several concerns were addressed and satisfactorily resolved. These included the need for an air permit, the need for additional machine guarding, overflow protection, and hearing protection.

A meeting was held with members of Waste Management, Quality, Product Engineering, Operations, and Waste Minimization. A brief history of the nitric acid waste stream was presented followed by a proposal to ultrasonically clean a specific part family as a feasibility study for replacing the nitric acid cleaning process with one using ultrasonic cleaning. All attendees agreed to the severity of the waste problems generated by the nitric acid stream and supported the concept of using ultrasonic cleaning as an alternative. D-38 wrought parts were chosen as the first part family to address because of their large throughput.

The first part type from this family was chosen because, due to its geometry, it was considered to be a worst case from an ultrasonic cleaning standpoint. An evaluation team was established to inspect the parts after cleaning. This team consisted of the Compliance Manager from the division receiving cleaned parts, a representative of Quality Engineering, and a representative from Product Engineering.

\section{EXPERIMENTAL}

An Ultrasonic Cleaning Procedure (00-Y-360) was written to allow parts to be processed through the ultrasonic facility. Product Engineering Transmittal 040279 was written to allow use of the Ultrasonic Cleaning Procedure and to reflect new routing requirements. 
Components of the Delta T Products ultrasonic rinse tank system used in these experiments included: (1) a control station containing a programmable logic controller, an annunciator for fault detection, and control interface devices, (2) three generator cabinets containing six each 1000 -W $20 \mathrm{khz}$ generator units, (3) a 900 gallon stainless steel tank with motorized access doors and an internal load elevator with maximum load dimensions of 59 inches in width and 42 inches in height and a load rating of 4200 pounds, (4) a water recirculation system with immersion type heaters, using a 250 micron stainless steel strainer and a 10 micron replaceable filter bag, and (5) sixteen transducers (20 khz rated operating frequency), with eight each being mounted in the front and back and adjusted to between 19 and $19.5 \mathrm{khz}$.

All experiments were conducted with the closed end of the part elevated approximately thirty degrees. This elevation allowed the removed materials to flow out of the part during cleaning. Parts were placed, two at a time, in the ultrasonic cleaner and the cycle, programmed for fifteen minutes, was started. At the end of this cycle, the part was rotated to expose portions that were in contact with the part carrier and the cycle was then repeated. This particular part required a rinse on the inside surfaces to remove a small amount of loose residual oxide that had been trapped. This was accomplished prior to removal from the tank.

\section{RESULTS}

Prior to cleaning, parts were black in color and were covered with a flaking oxide and scale. After cleaning, parts remained black but all flaking and loose oxide had been removed. Health Physics surveys also showed removable contamination levels to be within the limits required for transport between the operations areas. The evaluation team accepted the parts as cleaned and the parts resumed their normal routing.

\section{CONCLUSIONS}

Based on these results, the subject part type was added to Procedure 00-Y-360. In addition, the entire D-38 wrought part family will go through a cleaning and evaluation process as described in Production Engineering Transmittal 040279. Each part type, upon acceptance, will be added to Procedure 00-Y-360. While the ultrasonic cleaning on the part type included in the first experiment could be done with only two parts at a time, smaller parts having a less complex geometry should allow more than two parts per run to be cleaned. A final rinse step is not anticipated for these smaller parts.

The waste stream from the ultrasonic operation will initially consist primarily of oxide and water, although there exists an opportunity to eliminate the water from the waste stream by having a filter system that will allow recycle. Accumulated oxide will be removed from the tank by pumping the water out, removing the oxide, and pumping the water back to the tank. The wet oxide will be transported to the Uranium Chip Oxidation Facility (UCOF). Because this waste generation and transfer process is use dependent, the frequency remains to be determined.

\section{BENEFITS}

Several major benefits can be realized by replacing the nitric acid cleaning process for D-38 wrought parts with an ultrasonic cleaning process. These include: 
1. Significant reduction of waste volume at the WETF. With an $83 \%$ reduction in part throughput at the acid facility, ultrasonic cleaning will greatly reduce the volume of wastes from the acid, rinse, and mop water tanks, and will ease both the cost and difficulty of future disposal options.

2. The quantity of water waste generated by the ultrasonic process is expected to be lower than that generated in the nitric acid facility.

3. Water waste generated by the ultrasonic process will be sent to the Central Processing Facility which is considerably less expensive than the WETF. Acid wastes are much more difficult to treat than neutral wastes.

4. There will be a reduction in the quantity of uranium waste. The nitric acid process removes more metal, which is unnecessary, than does the ultrasonic cleaning process.

5. The uranium waste from the ultrasonic facility will be sent to the UCOF instead of the WETF, which again is less expensive.

6. The nitric acid life will be extended and is established to be less than, but near, the $83 \%$ level of throughput reduction.

7. Elimination of two building moves involving two RAD areas resulting in a part movement reduction of approximately $25 \%$. This is also a significant cost savings.

8. The opportunity to remove the water from the waste stream by combining the ultrasonic cleaning process with a filter process to recycle the water.

Replacing the current nitric acid cleaning facility with an ultrasonic cleaning facility will lessen the burden on the WETF. The wastes coming from the new facility will be lower in quantity and will be sent to other, less expensive facilities for treatment. This translates to a significant cost savings for waste treatment for the Metal Preparation Division and, in addition, will lessen the exposure of workers to hazardous materials (nitric acid). 
Distribution

L. A. Abbatiello

T. A. Arehart

J. K. Bailey

M. L. Baker

K. M. Cash

S. R. Churnetski

S. B. Derrington

G. W. Eckert

J. R. Gray

G. D. Hackett

J. E. Heiskell, Jr.

J. E. Keyes/DOE-OSTI (4)

J. W. Koger

A. P. Malinauskas

J. M. Napier

W. G. Northcutt

J. O. Moore/DOE-ORO

J. K. Prazniak

W. G. Reis

R. C. Riepe

C. B. Senviel

L. D. Snow/J. D. Kennedy

J. D. Stout

J. E. Thompson

T. H. Thrasher

J. P. Woodall

Y-12 Central Files

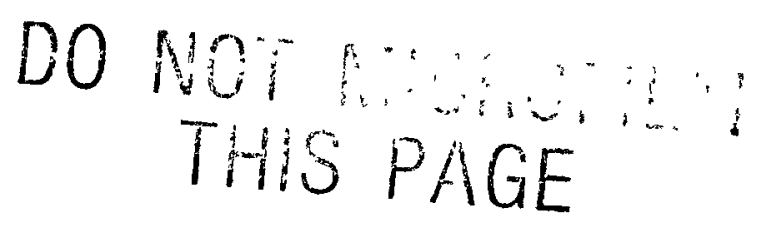

